\title{
High-Ca olivines in ultramafic and alkali lamprophyres of Kola alkaline province (Russia) as indicators of source heterogeneity
}

\author{
ALEXEI VOZNIAK* ${ }^{*}$, LYUDMILA SAZONOVA ${ }^{2}$, AND
} ANNA NOSOVA ${ }^{1}$

${ }^{1}$ GEOKHI RAS, Moscow, Russian Federation

(*correspondence: vulpesvulpesred@gmail.com)

${ }^{2}$ Lomonosov Moscow State University,Geological, Petrology,

Moscow, Russian Federation

There are more than 20 Paleozoic alkaline complexes in the Kola alkaline province, Russia, among them there occur dike swarms of alkaline and ultramafic lamprophyres - the Kandalaksha and Turiy Cape. The Kandalaksha aillikites and Turiy cape monchiquites contain olivine phenocrysts that can be used as a tool for recognizing the nature of mantle source and the earliest evolution of magmas.

Kandalaksha olivines are euhedral, with normal and reversed zonation, Fo varies from 84 to 87 , with moderate Ni and $\mathrm{Cr}$ concentrations (1200 - $2400 \mathrm{ppm} \mathrm{Ni}$; $200-600$ ppm $\mathrm{Cr}$ ), whereas $\mathrm{Ca}$ and $\mathrm{Mn}$ are extremely high (1500 - 2400 ppm Mn; 2400 до 3800 ppm Ca).

The Turiy Cape olivines are subrounded, with reversed zonation, they contain similar amounts of $\mathrm{Ca}$ and $\mathrm{Mn}$, but they are less magnesian (Fo - 82-85) and contain lower concentrations of $\mathrm{Ni}$ and $\mathrm{Cr}(400-800 \mathrm{ppm} \mathrm{Ni}$, up to $200 \mathrm{ppm}$ $\mathrm{Cr})$.

Calculations showed that the Kandalaksha and Turiy Cape olivines couldn't crystallize from the common initial melt, which is confirmed by a great difference of transitional elements concentrations.

Melts that produced high-Ca and low-Ni Turiy Cape olivines probably originated from wehrlite source, which has been formed as a result of mantle carbonate metasomatism[1], whereas the Kandalaksha olivines show significant contribution of peridotitic source.

The Turiy Cape olivines also contain primary inclusions of carbonate, which indicate carbonate-bearing initial melts.

This study was supported by the Russian Science Foundation under Grant No. 19-17-00024.

[1] Ammannati et al. (2016) Earth and Planetary Science Letters, 444, 64-74 